\title{
KIERTOTALOUS-SANAN TUNNETTUUS JA MERKITYSTULKINNAT
}

\section{Paula Sjöblom, Turun yliopisto, kieli- ja käännöstieteiden laitos}

\author{
Ville Virsu, Turun yliopisto, kieli- ja viestintäopintojen \\ keskus
}

Kestävä kiertotalous on talousmalli, jonka avulla voidaan hillitä luonnonvarojen ylikulutusta, torjua ilmastonmuutosta ja luonnon köyhtymistä samalla taloutta ja työllisyyttä vahvistaen. Uuteen malliin siirtyminen vaatii ajattelutapojen muutosta ja kiertotalouden käsitteen ymmärtämistä. Kansalaisille kiertotalous ei kuitenkaan ole kovin tuttu sana.

Tutkimus selvittää kiertotalous-sanan tunnettuutta ja merkityksen päättelyä ensimmäisen vuoden opiskelijoiden keskuudessa. Kyselytutkimus tehtiin Turun ja Itä-Suomen yliopistoissa kieltenopiskelijoille ja kauppatieteiden opiskelijoille vuosina 2019 ja 2020. Artikkelissa pohditaan kiertotalouden merkityksen päättelyä yhdysosien merkitysten perusteella sekä paneudutaan kyselyvastausten episteemistä modaalisuutta ilmaiseviin aineksiin. Siinä selvitetään myös vastaajien asenteita sekä sanan tunnettuudessa tapahtuneita kvantitatiivisia muutoksia.

Kiertotalous-sanan tunnettuus lisääntyi tutkimusjaksolla selvästi ja vastausten varmuusaste nousi, mutta epävarmuutta ilmaisevia modaalisuuden keinoja käytetään kummassakin osatutkimuksessa runsaasti. Vastauksissa käytetyt evidentiaalisuuden ilmaukset viittaavat yleensä omaan päättelyyn. Yhdyssanan edusosan talous perusteella merkitys liitetään 'talouselämään' tai 'talousjärjestelmään', mutta usein myös 'rahavaroihin'. Määriteosa kierto täsmentää tulkinnat useimmiten kiertää-verbin merkityksen 'vaihtaa omistajaa' tai 'kulkea kehää' mutta myös 'kaihtaa, välttää' -merkityksen pohjalta.

Avainsanat: kiertotalous, merkitys, modaalisuus, yhdyssanat

\footnotetext{
Kirjoittajien yhteystiedot: 


\section{JOHDANTO}

Tiedot ilmastonmuutoksesta, kasvihuonepäästöistä, luonnonvarojen ylikulutuksesta ja luonnon monimuotoisuuden köyhtymisestä ovat vähitellen löytäneet sijaa ihmisten ajattelussa. Sen myötä monet viranomaiset ja hallitukset ovat ymmärtäneet, että tarvitsemme globaalisti uusia toimintamalleja, jotka eivät pysäytä taloutta mutta muuttavat kulutusta kestävämpään suuntaan. (Ks. esim. WWF; Sitra, 2016.) Menestyvän talouden ja hiilineutraalin yhteiskunnan yhdistämisessä uudeksi mahdollisuudeksi on nähty siirtymä kestävään kiertotalouteen, joka tarkoittaa luonnonvarojen käytön vähentämistä, materiaali-, energia- ja ravinnekiertojen sulkemista sekä tuotteiden, materiaalien ja resurssien arvon säilymistä mahdollisimman pitkään (Ympäristöministeriö; CICAT2025). Tämä tarkoittaa, että tehdään kestäviä ja korjattavia tuotteita, kierrätetään materiaalit ja raaka-aineet turvallisesti, käytetään palveluja ja vuokrataan tai yhteisomistetaan. Myös Suomi on laatimassa kiertotalousstrategiaa tavoitteenaan tukea maan taloutta ja samalla välttää luonnonvarojen ylikulutusta. (Ympäristöministeriö; Kiertotalouden ekosysteemit, 2020, s. 9-10; Uusi suunta, 2021, s. 8, 11, 21-22.)

Valtioneuvoston julkaiseman kiertotalouden edistämisohjelman mukaan uuteen malliin siirtyminen vaatii kuitenkin laajaa asennemuutosta (Uusi suunta, 2021, s. 2124). Yleinen asenteiden muutos taas vaatisi kiertotalouden käsitteen konkreettista ymmärtämistä ja ajatuksen hyväksymistä. Termi kiertotalous on vielä suurelle yleisölle melko vieras, ja sitä on myös moitittu kielellisesti hämäräksi (Nuutinen, 2014). Jopa kiertotalouteen liittyvää liiketoimintaa harjoittavien yritysten edustajilla on sanasta monenlaisia tulkintoja, saati sitten ihmisillä, joiden päivittäisessä elinpiirissä asiasta ei puhuta. (Ks. esim. Kiertotalousohjelman kansalaisraati; Virsu \& Sjöblom, 2020.)
Kiertotalouden käsite on laaja ja vaikeasti hahmotettava, koska se koskee lähes kaikkia toimialoja. Keskeisiä ovat etenkin materiaalien kiertämiseen liittyvät toimialat. Työ- ja elinkeinoministeriön selvityksen mukaan materiaalikiertojen ja niitä tukevan palveluliiketoiminnan vuotuinen liikevaihto Suomessa on 11,4 miljardia euroa. Tällaiset yritykset toimivat monilla eri aloilla ${ }^{1}$, ja noin puolella näistä on liiketoimintamallinaan kierrätys. Muita liiketoiminnan malleja ovat resurssitehokkuuteen perustuva toimintatapa, jakamistalous, tuote palveluna -konseptit ja tuotteen elinkaaren pidentäminen. (Kiertotalouden ekosysteemit, 2020, s. 41-42, 44-46.) Useimmiten mainittujen liiketoimintamallien taloudellinen merkittävyys liittyy keskeisesti kuluttajien asenteisiin ja elintapoihin. Siksi kansalaisten käsitykset kiertotalouden sisällöstä ovat tärkeitä. Jos esimerkiksi kiertotalous ymmärretään pelkästään tuotteiden kierrätyksenä, jää suuri osa kiertotalousmallin mukaan toimivista yrityksistä kuluttajilta huomioimatta.

On oletettavaa, ettei suuri yleisö juuri seuraa esimerkiksi ylhältä hallinnosta johdettujen kiertotaloushankkeiden ja -ohjelmien keskustelua eikä voi siten tästä diskurssista oppia käsitteen merkitystä. Valtaosalla ihmisistä ei ole erityistä motivaatiota perehtyä kiertotalousaiheeseen, eivätkä he etsi siitä tietoa esimerkiksi internetistä. Sen sijaan ihmisiä kiinnostavat omaan elämään liittyvät kulutusvalinnat, jotka hyvin usein kytkeytyvät kiertotalouteen ilman, että sitä tiedostetaan: auton hankinta, ulkomaanmatka, kodin energiaratkaisu, päivittäiset ateriat jne. Jos kansalaisten

1 Muutamina esimerkkeinä lukuisista eri aloista mainittakoon vaikkapa metalliromun keräys, akkujen kierrätys, paperinkeräys, puupohjaisten pakkausmateriaalien valmistus, tuhkalannoitteiden valmistus, jätepolttoaineet, hukkalämmön hyödyntäminen, biokaasu, muovin kierrätys, jätehuolto, kierrätyslannoitteet, elintarviketeollisuuden sivuvirtojen käyttö ja älykkäät kasvihuoneet (Kiertotalouden ekosysteemit, 2020: 46). 
halutaan ymmärtävän, mistä kiertotaloudessa on kysymys, pitää kiertotalouspuheen näkyä niillä lehtien, television, sosiaalisen median ja mainonnan kanavilla, joita ihmiset muutenkin seuraavat. $^{2}$

Tämän kirjoituksen tavoitteena on kyselytutkimuksen avulla tarkastella kiertotaloussanan tulkintoja ja niissä tapahtuneita muutoksia. Olemme kiinnostuneita erityisesti siitä, millä tavoin kyselytutkimuksen vastaajat päättelevät tämän erikoiskieleen kuuluvan uudissanan merkityksen yhdyssanan osien perusteella ja miten he merkitsevät vastauksensa epävarmaksi tai varmaksi. Vertaamme vuonna 2019 ja 2020 tekemiemme kyselyiden tuloksia toisiinsa ja samaan aikaan mediassa esiintyneiden kiertotalousaiheisten juttujen määrään. Kysymme, onko kiertotalous-käsitteen tunnettuudessa tapahtunut muutosta, ja jos, niin korreloiko tunnettuus julkisen keskustelun määrän kanssa. Tutkimme myös, miten sanaan liittyvät asenteet ovat muuttuneet noin puolentoista vuoden tutkimusajanjakson kuluessa.

Tutkimus liittyy Suomen Akatemian Strategisen tutkimuksen neuvoston rahoittamaan monitieteiseen hankkeeseen, jossa selvitetään kiertotalouteen siirtymistä vauhdittavia tekijöitä (CICAT2025). Kieltä tutkitaan siinä yhtenä muutoskatalyyttina. Aiemmin on selvitetty kiertotalous-sanan käyttöä kehyssemanttisesta näkökulmasta kansalaisilta vuonna 2019 kerätyissä kyselyvastauksissa (Virsu \& Sjöblom, 2020) sekä Helsingin Sanomien teksteissä (Läärä, 2020).

2 Ongelma ei ole tietenkään pelkästään kuluttajien, ns. suuren yleisön, tietämyksessä, vaan myös eri alojen välisessä kommunikaatiossa, koska termi ymmärretään eri tavoin eri aloilla. Tarvitaan siis laajaa, siilot ylittävää yhteistyötä ja yhteisymmärrystä, mikä edellyttää toimivia viestintäkäytäntöjä (ks. esim. Sumter ym., 2020).

\section{AINEISTO JA MENETELMÄ}

Selvitimme keväällä 2019 toteutetulla kyselyllä, miten yliopisto-opiskelijat tunnistavat, määrittelevät ja kehystävät sanan kiertotalous. Kyselyyn vastasi yhteensä 204 ensimmäisen vuoden opiskelijaa Turun yliopiston kauppakorkeakoulusta ja humanistisesta tiedekunnasta sekä Itä-Suomen yliopiston kauppatieteiden laitoksesta. Valtaosa vastaajista oli iältään 20-27-vuotiaita. (Ks. myös Virsu \& Sjöblom, 2020.)

Toistimme saman kyselyn syksyllä 2020 Turun yliopiston humanistisen tiedekunnan ensimmäisen vuoden kieltenopiskelijoiden keskuudessa. Vastaajajoukko oli siis rakenteeltaan melko samankaltainen kuin kevään 2019 vastaajajoukko: korkeakouluopintonsa vasta aloittaneet, pääosin 20-28-vuotiaat ylioppilaat. Erona oli kauppatieteitä opiskelevien puuttuminen tästä jälkimmäisestä ryhmästä. Vastauksia jälkimmäiseen kyselyyn saimme yhteensä 103 eli noin puolet vuoden 2019 opiskelijavastaajien määrästä.

Kummassakin kyselyssä lomakkeen määrittelytehtävä kuului seuraavasti: "Kuvaile vapaasti, mitä mielestäsi merkitsee sana kiertotalous, mihin kiertotalous liittyy tai mitä mielikuvia sana sinussa herättää?” Vastaukset annettiin kirjallisesti, ensimmäisellä kerralla käsin paperille kirjoittaen, toisella kerralla verkkolomakkeelle naputellen. Kummallakin kerralla vastausaikaa annettiin vain joitakin minuutteja. Ohjeistuksessa korostettiin sitä, että kyselyllä tavoiteltiin välittömiä mielleyhtymiä ja arkiymmärrystä eikä niin sanottuja oikeita vastauksia, ja siksi vastaajia kiellettiin käyttämästä apuna hakukoneita tai sanakirjoja. Lomake ei tarjonnut sanalle valmiiksi mitään käyttökontekstia, jotta kaikki vastaukset perustuisivat puhtaasti vastaajan omiin tulkintoihin. (Ks. myös Virsu \& Sjöblom, 2020.) Lomakkeen lopussa esitettiin seuraavat kaksi kysymystä: 1) "Kuinka kiinnostu- 
nut olet kiertotaloudesta ilmiönä ja esim. sitä käsittelevästä julkisesta keskustelusta?" 2) "Miten suhtaudut kiertotalouden kehittämiseen ja edistämiseen yleisesti, yhteiskunnallisena ja kansantaloudellisena asiana?” Näihin vastattiin asteikolla 1 (en lainkaan kiinnostunut / en lainkaan tärkeänä) -10 (erittäin kiinnostunut / erittäin tärkeänä).

Ensimmäisen kyselyn vastausten analyysissa mielenkiintomme kohdistui erityisesti siihen, miten kiertotalous-käsitteen kontekstia oli kyselyvastauksissa rakennettu: millaiseen käsiteverkkoon eli kehyksiin se sijoitettiin ja millaisiin konkreettisiin asioihin se kiinnitettiin (Virsu \& Sjöblom, 2020). Tässä artikkelissa tutkimme itse kiertotalous-sanaa ja sen merkityksentulkintaa. Selvitämme, miten vieraan tai vieraahkon sanan merkitystä päätellään yhdyssanan osien merkitysten perusteella eli miten ymmärretään kierto ja miten talous ja miten näistä rakentuu koko käsitteen tulkinta. Paneudumme myös käsitteen yleisessä tunnettuudessa tapahtuneisiin muutoksiin ja tarkastelemme vastaajien käsityksiä omista tulkinnoistaan analysoimalla vastausten modaalisia aineksia ja etenkin sitä, missä määrin ja minkä asteista episteemistä modaalisuutta eli tulkinnan varmuusastetta vastaukset sisältävät.

Käsitteen tunnettuudessa tapahtuneita muutoksia selvitämme kvantitatiivisesti suhteuttamalla tyhjäksi jätettyjen vastausten, lyhyiden en tiedä -tyyppisten vastausten sekä "väärien" vastausten määrän vastaajien kokonaismäärään. "Vääriksi" luemme vastaukset, jotka eivät sisällä yhtään merkityspiirrettä kiertotalouden vakiintuneista määritelmistä (ks. Virsu \& Sjöblom, 2020). Laskemme myös asteikkokysymysten keskiarvon ja mediaanin ja vertaamme eri vuosien kyselyjen tuloksia toisiinsa. Lisäksi olemme selvittäneet, miten usein Helsingin Sanomien ja Ilta-Sanomien kirjoituksissa kiertotalous-sana on esiintynyt kunakin vuonna ajalla 2016-2019. Poimin- nat on tehty Sanoma-arkiston verkkosivulla hakusanalla kiertotalous 23.11.2020. Näin saadut tulokset kertovat osaltaan aihetta käsittelevän julkisen keskustelun määrästä, jota vertaamme kyselyvastausten kvantitatiivisiin tuloksiin.

\section{KIELITIETEELLISTÄ TAUSTAA}

\subsection{Kiertotalous sananmuodostuksen näkökulmasta}

Suomen kielen sananmuodostustavoista yhdistäminen on yleisin keino tuottaa kieleen uusia sanoja. Prototyyppinen uusi yhdyssana on kahdesta substantiivista koostuva nominatiivialkuinen muodoste. (Tyysteri, 2015, s. 41, 207.) Kiertotalous on juuri tällainen kahdesta itsenäisestä substantiivista koostuva nominatiivialkuinen määritysyhdyssana. Määritysyhdyssanalle tyypillisesti se ilmaisee jollain tavalla rajattua asiaa, joka on alakäsite yhdyssanan edusosalle talous. Tämäntyyppisten yhdyssanojen merkitys syntyy yhdysosien merkityksen perusteella tai on sopimuksenvarainen. (VISK $₫ 400$, s. 408-409.) Kiertotalouden sanakirjamerkitykseksi on annettu 'talous jossa hyödykkeiden arvo säilytetään mahdollisimman pitkään mm. kierrätyksen ja uudelleenkäytön avulla' (Kielitoimiston sanakirja, 2018). Erikoiskielisessä käytössä sana sisältää tätä moniulotteisempia merkityspiirteitä, koska sen kuvaama käsite liitetään koko yhteiskunnan systeemin muutokseen (ks. esim. Webster, 2013; Virsu \& Sjöblom, 2020).

Vapainta ja assosiatiivisinta merkityksen muodostuminen on nimenomaan nominatiivialkuisilla yhdyssanoilla (VISK $₫ 408-$ 410). Morfologisesti yksinkertainen rakenne on vastaanottajan kannalta hankala: tieto on pakattu siihen tiiviisti, minkä vuoksi uuden sanan merkitys ei avaudu helposti ilman maailmantietoa tai tietoa kontekstista. Jos sana on vieras eikä kontekstia ole saatavilla, vastaanot- 
taja pyrkii hahmottamaan sanan merkitystä nimenomaan yhdysosien kautta. (Tyysteri, 2015, s. 208.)

Laura Tyysterin $(2015$, s. 45, 47) mukaan nominatiivialkuisten yhdyssanojen merkityksen tutkimiseen sopii hyvin funktionalistinen yhdyssanateoria, jota on suomalaisessa yhdyssanatutkimuksessa esitellyt Lauri Seppänen (1981 < Coseriu, 1971, 1975). Funktionalistinen malli korostaa yhdyssanan osien merkityssuhteen määräytymistä vasta käyttökontekstissa eikä niinkään kielen systeemin tasolla: yhdyssana on leksikaalisessa systeemissä yksikkö, jonka merkityksessä yhdysosilla on vain jokin suhde toisiinsa, mutta kontekstissa merkitys saa lisäpiirteitä ja lopullisen tulkintansa (Seppänen, 1981, s. 74; yhdyspaikannimien osalta vastaavaa ajattelua edustaa mm. Kiviniemi, 1987, s. 20). Tutkimusasetelmamme kaltaisessa tilanteessa, jossa kielenkäyttäjällä ei ole saatavilla merkitystulkintaa ohjaavaa kontekstia, pyritään merkitys tulkitsemaan yleisen maailmantiedon ja puhujan ennestään tuntemiin yhdyssanoihin liittyvien analogioiden pohjalta. Tuttu malli (muotti, skeema) ohjaa uuden yhdyssanan tulkintaa ja avaa käsitteen mahdollista merkitystä ilman, että vastaanottaja tuntisi sanan määritelmää tai käyttökontekstia (ks. Pitkänen, 2008, s. 102).

Kiertotaloutta voi pitää uudissanana, sillä se on ilmestynyt Kotimaisten kielten keskuksen uudissanapoimintoihin vuonna 2014.
Kielitoimiston verkkosanakirjaan se on otettu vuonna 2017. (Kotus, uudissanapoiminnat, 2014; Läärä, 2020, s. 21.) $)^{3}$ Kansainvälisissä yhteyksissä kiertotaloudesta (circular economy) on puhuttu 1990-luvulta asti, mutta sen sisältöön on kehittynyt maailmassa erilaisia painotuksia eri sosio-kulttuuristen ja poliittisten järjestelmien mukaan (Winans, Kendall \& Deng, 2017, s. 826). Alun perin kiertotalous ja sen lähikäsitteet on kehitetty ympäristötieteiden tutkimus- ja viestintätarpeisiin, mutta sana on levinnyt, ja se kuuluu nykyisin monien eri alojen, kuten talouden, ekologian ja systeemitieteiden, erikoiskieleen. Kunkin alan intressien mukaan se saa omanlaisiaan merkityssisältöjä. Suomessa tuorein poliittinen määritelmä löytyy Valtioneuvoston tammikuussa 2021 julkaisemasta kiertotalouden edistämisohjelmasta:

Kiertotaloudessa materiaaleja hyödynnetään tehokkaasti ja kestävästi ja ne pysyvät kierrossa pitkään ja turvallisesti. Tuotteita myösjaetaan, vuokrataan, korjataan ja kierrätetään. Palvelullistaminen on osa kiertotaloutta.

Kiertotalous on uusi talouden toimintatapa, joka tuottaa taloudellista hyvinvointia maapallon kantokyvyn rajoissa. Se byödyntää digitalisaatiota tehokkaasti ja uudistaa ybteiskunnan rakenteita ja toimintamalleja. Kiertotalous on keino vähentääluonnonvarojen käyttöä. (Uusisuunta, 2021, s. 26.)

3 Kiertotalous-sana on esiintynyt lehdistössä jo 1920-luvulla, mutta tällöin sillä on viitattu esim. kaskiviljelyyn tai hylkeenpyyntiin liittyvään elintapaan, erätalouteen. Suomen sanomalehdissä varhaisimmat yksittäiset nykymerkityksiset sanaesiintymät löytyvät kuitenkin jo vuosilta 1973 ja 1980: Joulukuussa 1973 Maaseudun Tulevaisuus -lehdessä oli Terho Vitikaisen laatima artikkeli, jossa esiintyy maininta luonnonvarojen kiertotalous ja uudelleenkäyttö. Helmikuussa 1980 Maaseudun Tulevaisuus ja Etelä-Suomen Sanomat julkaisivat artikkelin Helsingin yliopiston Studia Generalia -esitelmän pohjalta, jossa maa- ja metsätalousministeriön luonnonvarainhoitotoimiston dosentti Pertti Seiskari kuvasi teollisen talouden olevan muuttumassa "kiertotaloudeksi, joka on säästämisen ohella lopulta ainoa tapa ehkäistä jatkuvaa ympäristön saastumista ja pilaantumista". Seuraavan kerran sana mainitaan tekniikan tohtori Johanna Kirkisen kirjoittamassa vierasyliössä Maaseudun Tulevaisuudessa 4.2.2013. Siinä näkökulma on maatalouden kiertotaloudellistumisessa. Vuodesta 2014 lähtien sanomalehdissä sanaa käytetään jo enemmän, mutta alkuvaiheessa nimenomaan Maaseudun Tulevaisuus ja Etelä-Suomen Sanomat käyttävät sanaa selvästi muita useammin. (Kansalliskirjasto, digitaaliset sanomalehtiaineistot.) 
Erikoiskielellä tarkoitetaan tiettyjen käyttäjäjoukkojen tietyissä yhteyksissä käyttämää kielimuotoa ${ }^{4}$. Erikoiskieliin kehitetyt sanat ovat termejä, ja niiden pitää olla merkitykseltään yksiselitteisiä eli tarkasti määriteltyjä. Uudissanan ja varsinkin uuden termin muodostamisen motiivina on usein tarve puhua jostain uudesta asiasta tai ilmiöstä. Kiertotaloudesta taas voidaan puhua ehkä paremminkin käsitteenä, jonka elementit ovat kyllä aiemminkin olleet olemassa (asia ei sinänsä ole uusi), mutta joka on hahmotettu uudella tavalla ja jonka rajat ja merkityspiirteet on haluttu määritellä. (Ks. esim. Karihalme, 1996, s. 36, 39; Laine, 2007, s. 58-59; Zgusta, 1990, s. 389,393 .) Sanalla on havaittavasti käyttöä myös yleiskielessä, mutta koska se on uudehko, voi olettaa sen merkityksen olevan monille edelleen melko vieras.

Kiertotalous-yhdyssanan edusosana oleva substantiivi talous on Tyysterin (2015, s. 171-172) laskelmien mukaan toiseksi yleisin jälkiosalekseemi sellaisissa uusissa yhdyssanoissa, joiden alkuosa on nominatiivimuotoinen substantiivi. Kielenkäyttäjillä on siis tulkintojensa analogisina malleina runsaasti erilaisia talous-loppuisia yhdyssanoja (esim. markkinatalous, suunnitelmatalous, maatalous). Talous-sanan sanakirjamerkityksiä ovat paitsi 'talouselämä, aineellisten tarpeiden tyydyttämistä hoitava yhteiskunnallinen järjestelmä tai ylipäätään 'jotakin ylläpitävää järjestelmä myös suppeammin 'taloudellinen asema, varat,' 'taloudenhoito' ja 'ruokakunta' (Kielitoimiston sanakirja, 2018).

Määriteosan substantiivi kierto on deverbaali johdos, joka näin tuo yhdyssanaan verbaalia merkitystä (ks. myös Tyysteri, 2015, s. 119). Kielitoimiston sanakirjan (2018) mukaan kierto-sanan merkitys voi olla muun muassa 'pyöritys, pyörähdys, liike pituusakselin ympäri,' 'radan tms. kiertäminen', 'siirtyminen

4 Erikoiskielistä lisää esim. Pitkänen, 2008, s. 114119. yhdeltä toiselle tai asemasta toiseen', 'viljelykasvien vuorottelu'. Nämä kaikki merkitykset pohjautuvat kantaverbin kiertää lukuisiin eri merkityksiin: 'pyörittää, vääntää, kääriä, 'kulkea jnk. ympäri (umpinaista rataa), ympäröidä, 'kulkeutua yhdeltä toiselle, vaihtaa omistajaa,' 'pyöriä. Näiden lisäksi verbille on sanakirjassa listattu muunkinlaisia merkityksiä, joihin viittaavia tulkintoja voi osin havaita tutkimuskyselyn vastauksista. Tällaisia ovat mm. 'kulkea kaartaen, päätyä kiertoteitse', 'kaartaen sivuuttaa, välttää, karttaa, kaihtaa', 'kulkea, kuljeksia, harhailla'. (Kielitoimiston sanakirja, 2018.)

Määritellessään itselleen vieraan kiertotalous-sanan merkitystä ilman kontekstia vastaajat ovat siis joutuneet turvautumaan tuttujen sanojen kierto ja talous merkityksiin ja muiden vastaavien, tuntemiensa yhdyssanojen käyttöyhteyksiin ja merkityksiin. Osalle vastaajista sana on toki ainakin jossain määrin tuttu ennestään, ja näistä osa tuntee sanan käyttöyhteydet ja kykenee niiden perusteella kuvailemaan sanan merkityksen lähes termimääritelmän mukaisesti. Sanan tuttuutta vastaajalle voidaan arvioida paitsi vastausten sisällön myös vastausten modaalisten ainesten perusteella.

\subsection{Kiertotalous-sanan määritelmät modaalisuuden näkökulmasta}

Modaalisuuden määritteleminen ei ole yksiselitteistä (ks. pohdintaa esim. Elsayed, 2017, s .4-29), mutta tavallisesti sitä pidetään kieleen merkittynä puhujan arviona sanotun asian todenmukaisuudesta tai toteutumismahdollisuuksista. Suomen kieliopissa sitä ilmaistaan monin eri tavoin, kuten tietyin lausemuodoin, verbein, verbimuodoin, adverbein ja adjektiivein. Kielen modaalisuus perustuu siihen, että puhujalla on mielessään ikään kuin vaihtoehtojen, sanotun toteutumisen eri mahdollisuuksien joukko. Asiantilaa voidaan arvioida sen mahdollisuuden 
(episteeminen modaalisuus) tai välttämättömyyden (deonttinen modaalisuus) pohjalta. Sisäistä tai ulkoista kykyä tai pakkoa taas ilmaistaan dynaamisella modaalisuudella. Kun puhuja ilmaisee jollain tavoin sanotun tiedon lähteen (esim. havainto, kuulopuhe), on kyse evidentiaalisuudesta. Suomessa tiedon lähteen kieliopillinen merkintä sisältää myös arviointia asiaintilan mahdollisuudesta, minkä vuoksi evidentiaalisuutta pidetään meillä modaalisuuden alakategoriana, toisin kuin monissa muissa kielissä, joissa evidentiaalit merkitsevät ainoastaan puhujan tietolähdettä ilman arviota tiedon varmuusasteesta tai totuudenmukaisuudesta. (VISK $\$ 1551-1553$; Tieteen termipankki; Aikhenvald, 2018.)

Kyselyvastaukset voidaan jakaa kahteen ryhmään: vastaukset, joissa todetaan asiantila ilman erityisiä modaalisia aineksia, ja vastaukset, joissa esiintyy modaalisia aineksia. Yleensä kyselyn vastaaja merkitsee vastauksensa varmuusasteen ja mahdollisesti myös osoittaa, mihin vastauksessa esitetty tieto perustuu. Lyhyitä tietämättömyyttä ilmaisevia vastauksia, kuten en tiedä, ei tietoa, ei aavistustakaan, ei mitään hajua, sana ei herätä minkäänlaisia mielikuvia, emme tässä laske mukaan asian varmuusastetta arvioivien vastausten joukkoon, vaikka toki episteemisiä ilmauksia nekin ovat: ne esittävät varmana vastaajan tietämättömyyden. Aineistossa on myös fragmentaarisia tai väitelauseen muotoisia, määritelmän kaltaisia vastauksia, joita emme tarkastele modaalisuuden näkökulmasta, olivat ne sitten asian jäljillä (esim. 1) tai eivät (esim. 2):

(1) Talouden malli jossa erilaiset kulutushyödykkeet kiertävät kestävän kehityksen mukaisesti elinkaarensa loppuun saakka.

(2) Verosuunnittelu, Panama, harmaampi kuin Kouvola.
Episteemisessä modaalisuudessa kyse on tavallisesti siitä, että puhuja ilmaisee epävarmuuttaan eli tuo esiin muidenkin mahdollisten totuuksien olemassaolon. Sitä ilmaistaan esimerkiksi kysymyslausein, modaalisin partikkelein ja adverbein (esim. ebkä, varmaankin), modaaliverbillä (saattaa, voida, taitaa) tai moduksista potentiaalilla. Myös uskomista, luulemista, arvelua tai tietämistä kuvaavat mentaaliset verbit (esim. luulla, arvella) ovat merkitykseltään modaalisia. Episteemisen modaalisuuden ilmaisut muodostavat jatkumon, jonka toisessa päässä ovat mahdottomaksi arvioidut ja toisessa päässä todennäköiseksi tai varmaksi arvioidut asiaintilat. (VISK $\$ 1556,1578$.) Aineistomme kirjallisissa vastauksissa esiintyy epävarmuuden ilmaisimina myös kysymysmerkkejä, kolmea pistettä ja jopa $\ddot{o}$-imitatiivia.

Evidentiaalisuus osoittaa, mistä ilmaistu tieto on peräisin. Suomen kielessä evidentiaalisuus kytkeytyy episteemiseen modaalisuuteen. Samalla kun evidentiaaliset ilmaukset ottavat kantaa tiedonlähteeseen, ne sisältävät myös kerrotun tiedon epävarmuuteen liittyviä merkityksiä. Puhujan epävarmuutta tuodaan esiin esimerkiksi sellaisilla ilmauksilla kuin kuulemma tai muka, joilla sanottu voidaan esittää kuulopuheeksi, kun taas esimerkiksi partikkelit siis tai varmaankin esittävät sanotun puhujan päättelyyn perustuvaksi. Evidentiaalisuutta ovat myös havaintoon, tietämiseen ja muistamiseen liittyvät ilmaukset, kuten näyttää, tietääkseni ja muistaakseni. (VISK \1557; vrt. Aikhenvald, 2018.) Kyselyvastauksissa esiintyy erityisesti vastaajan omaan päättelyyn liittyvää evidentiaalisuutta.

Olemme tässä tutkimuksessa kiinnostuneita nimenomaan vastauksissa ilmenevästä episteemisestä modaalisuudesta ja evidentiaalisuudesta, koska haluamme selvittää, miten varmoiksi tai epävarmoiksi vastaajat 
merkitsevät määritelmänsä. Emme siis kiinnitä huomiota vastausten harvinaisiin, joskin toki mahdollisiin, deonttisiin tai dynaamisiin merkityspiirteisiin 5 .

\section{KVANTITATIIVISET}

\section{TULOKSET: KIERTOTALOUDEN YLEINEN TUNNETTUUS JA MEDIANÄKYVYYS}

Tässä luvussa laskemme kyselytutkimuksen määrittelytehtävän ja kahden asteikkokysymyksen vastausten pohjalta, onko kiertotalous-käsitteen tunnettuudessa ja siihen liittyvissä asenteissa tapahtunut vuosien 2019 ja 2020 välillä muutosta. Vertaamme myös tuloksia siihen, miten paljon kiertotalous on ollut esillä mediassa kyselyjä edeltävänä aikana.

Pidämme sanan merkitystä vastaajalle tuntemattomana kolmella eri perusteella: 1) jos vastaaja on jättänyt kokonaan vastaamatta, 2) jos vastaaja on kirjoittanut en tiedä -tyyppisen vastauksen ilman mitään kiertotalouden vakiintuneisiin merkityspiirteisiin viittaavia lisäyksiä tai 3) vastaaja on kuvannut merkityksen täysin väärin. Alkuvuodesta ja keväällä 2019 kiertotalous-sanan merkitystä ei tuntenut lainkaan 51 prosenttia (104/204) Turun yliopiston ja Itä-Suomen yliopiston opiskelijavastaajista. Kieltenopiskelijoiden ja kauppatieteiden opiskelijoiden välillä ei vastauksissa ollut eroa. Syksyllä 2020 opiskelijavastaajista enää 21 prosenttia (22/103) ei tiennyt sanan merkitystä, joten muutos sanan yleisessä tunnettuudessa oli huomattava.

Ensimmäisessä kyselyssä 22 vastaajaa (10,8 \% kaikista) jätti määrittelykysymykseen kokonaan vastaamatta tai vastasi pelkästään $e n$ tiedä-, termi ei ole minulle tuttu-, en ole kuullut termiä ennen -tyyppisesti. Muut vastaajista, joille sana oli täysin vieras, joko pehmensivät

5 Dynaamista sisäistä välttämättömyyttä ilmaistaan esimerkiksi vastauksessa Positiivisia mielikuvia herää kiertotaloutta ajatellessa ja tulee olo että sitä pitäisi harjoittaa enemmän itse (2019). en tiedä -tyyppistä vastaustaan erilaisin epävarmuuden osoittimin (esim. 3 ja 4 ) tai arvasivat tai päättelivät sanan merkityksen virheellisesti. Monissa arvauksissa ja päättelyissä esiintyy episteemistä modaalisuutta ja omaan päättelyyn viittaavaa evidentiaalisuutta (esim. 5 ja 6), mutta jotkut esittävät virheellisen vastauksensa ikään kuin tosiasiana ottamatta kantaa sanomansa varmuuteen (esim. 7).

(3) Tuttu sana, mutta todellinen merkitys ei ole auennut.

(4) En valitettavasti ole varma, mitä se tarkoittaa.

(5) Mieleen tulee sosialismi.

(6) En ole ikinä kuullut, mutta kuulostaa joltain uudelta menetelmältä hoitaa taloutta.

(7) Kiertotaloudessa yhteiskunnan varoja laitetaan kiertämään yhteisen hyvän vuoksi ja näin saadaan asiat rullaamaan.

Vuoden 2020 vastaajista 8 (7,8 \%) jätti kohdan tyhjäksi tai vastasi en tiedä -tyyppisesti ilman modaalisia aineksia. Loput 14 sanaa tuntemattomista käyttivät samankaltaisia vastausstrategioita kuin edellä on kuvattu (esimerkit 8-10).

(8) Tiedän suurinpiirtein mitä kiertotalous tarkoittaa, mutta en osaa sitä kovin selkeästi selittää.

(9) En tiedä tarkkaa tarkoitusta mutta mieleen tulee jonkinlainen taloudellinen systeemi jonka osat varioivat jotenkin keskenään. Käsite liittyy jotenkin kansantalouteen ja sen kiertokulkuun.

(10) Rahan kiertämistä ekonomiassa, yrityksiltä, yksityishenkilöiltä ja valtiolta toisilleen. 
On selvää, että tulokset eivät suoraan kerro siitä, miten hyvin kiertotalous-sana tunnetaan, sillä niissä vastauksissa, joihin sisältyy edes joitain "oikeita" merkityspiirteitä, on samalla tavoin arvauksia ja omia päätelmiä kuin "väärissäkin" vastauksissa. Toisaalta esimerkkien $3 \mathrm{ja}$ 8 kaltaisilla vastaajilla saattaa olla oikeansuuntainen käsitys sanan merkityksestä, vaikka sitä ei ole vastaukseen kirjoitettu. Muun muassa esimerkin 11 kaltaisia vastauksia, joissa sanalle annetaan kaksi tai useampia vaihtoehtoisia merkityksiä, joista ainakin yksi on jossain määrin oikeansuuntainen, ei ole laskettu sanaa tuntemattomien joukkoon. Laskelmat ovat siis vain suuntaa antavia, mutta tulokset kertovat kuitenkin ymmärtääksemme siitä, että sanasta on puolessatoista vuodessa muodostunut jo jonkinlainen käsitys: se osataan yhdistää tietynlaisiin konteksteihin ja yhdyssanan osien merkitystä kyetään näin tulkitsemaan jo oikeansuuntaisesti.

(11) Kiertotalous voisi tarkoittaa talousmallia, jossa raha liikkuu kiertäen ilman hävikkiä osastolta toiselle. Toisaalta se voisi tarkoittaa kestävään kehitykseen liittyvää taloutta. (2019)

Paitsi sanan merkityksen tunnettuudessa myös itse ilmiöstä kiinnostumisessa ja siihen asennoitumisessa on tutkimusaikana tapahtunut selvä muutos. Kysyimme, kuinka kiinnostunut vastaaja on kiertotaloudesta ja sitä koskevasta julkisesta keskustelusta asteikolla 1-10. Vuonna 2019 näiden vastausten keskiarvo oli 3,88 ja mediaani 4, kun taas vuonna 2020 vastausten keskiarvo oli selvästi korkeampi, 5,67, ja mediaani 6. Toinen kysymys koski vastaajien asenteita, suhtautumista kiertotalouden kehittämiseen. Samanlaisella asteikolla vuoden 2019 vastausten keskiarvo oli 5,14 ja mediaani 5, ja vuonna 2020 vastausten keskiarvo oli 7,28 ja mediaani 8 .
Kiinnostuneisuus oli siis puolentoista vuoden aikana lisääntynyt ja asenteet olivat muuttuneet myönteisemmiksi.

Tulokset ovat selitettävissä monin tavoin. Esimerkiksi lukio-opetuksessa on aihepiiriä ehkä käsitelty entistä enemmän, mikä voi välittömästi näkyä ensimmäisen vuoden opiskelijoiden vastauksissa. Muutama yksittäinen vastaaja ilmaisikin suoraan kuulleensa asiasta jotain lukiossa tai lukeneensa siitä ylioppilaskirjoituksiin. Lisäksi nuoret seuraavat ilmastokeskustelua yhä tiiviimmin. Kiertotalouspuheella on sisällöllinen yhteys ilmastodiskurssiin, joten sitä kautta sana on voinut osua lukijan silmiin ja kuulijan korviin. Helsingin Sanomissa ja Ilta-Sanomissa julkaistujen juttujen perusteellakiertotalous-sanan esiintymät ovat lisääntyneet, joten sanaan törmää mediaa seuratessaan yhä useammin. Taulukossa 1 esitetään maan suurimman päivälehden, Helsingin Sanomien, ja viihteellisen iltapäivälehden, Ilta-Sanomien, osumat sanalle kiertotalous vuosina 2016, 2017, 2018 ja 2019.

TAULUKKO 1. Kiertotalous-sanan osumat (kpl) Helsingin Sanomien (HS) ja IltaSanomien (IS) jutuissa.

\begin{tabular}{|c|c|c|}
\hline Vuosi & HS & IS \\
\hline 2016 & 50 & 2 \\
\hline 2017 & 65 & 7 \\
\hline 2018 & 89 & 8 \\
\hline 2019 & 128 & 11 \\
\hline
\end{tabular}

Sekä Helsingin Sanomat että Ilta-Sanomat ovat valtakunnallisia sanomalehtiä, joilla on paljon lukijoita. Profiililtaan ne poikkeavat toisistaan, mikä näkyy selvästi myös kiertotalous-osumien kokonaismäärissä. Kiertotalous esiintyy Helsingin Sanomissa selvästi talouspuheessa: osumista kaksi kolmannesta sijoittuu talousmallin kehykseen (Läärä, 2020, s. 24). 
Syksyllä 2020 kyselyyn vastanneet olivat todennäköisesti törmänneet mediaa seuratessaan sanaan kiertotalous huomattavasti useammin kuin alkuvuonna 2019 kyselyyn vastanneet opiskelijat. Sana oli alkanut kuulostaa tutulta, vaikka sen täsmällinen merkitys olikin monelle vielä vieras. Tästä kertoo myös tyhjien ja lyhyiden en tied ä vastausten suhteellisen osuuden väheneminen.

\section{KVALITATIIVISET TULOKSET: YHDYSSANAN MERKITYKSEN PÄÄTTELY JA SEN VARMUUSASTEEN OSOITTAMINEN}

Tässä luvussa tarkastelemme päättelyketjujen ja modaalisuuden näkökulmasta kaikkia kyselyvastauksia, joissa on jollain tavoin pyritty muotoilemaan tutkittavalle sanalle jokin merkitys. Osoitamme erilaisia tulkintatapoja ja vastauksen varmuusasteen ilmaisuja esimerkkien avulla emmekä pyri kuvaamaan tyhjentävästi erilaisten tapausten osuuksia aineistossa.

\subsection{Episteeminen modaalisuus kyselyvastauksissa}

Vuoden 2020 vastaukset ovat yleisesti ottaen varmempia kuin vuoden 2019 vastaukset. Niissä on useita esimerkkien 12 ja 13 kaltaisia - mutta myös tiiviimmin ilmaistuja - määritelmiä, joissa kiertotalouden merkityspiirteitä ja käsitteen sisältöä kuvataan vakiintuneen merkityksen suuntaisesti, jopa tieteellisen tarkasti ja yksiselitteisesti indikatiivisin väitelausein. Vuoden 2019 aineistossa sen sijaan vastaavia esiintyy vain muutamia. Modaalisuuden näkökulmasta indikatiivi ilmaisee kategorisen väitteen, jonka episteeminen varmuusaste on suuri (VISK $\$ 1590$ ).

(12) Kiertotalous merkitsee kaikkien mahdollisten kierrätettävien ja uusiokäytettävien materiaalien, kuten energian, kaiken materiaalin ja aineksen, käyttämistä uudelleen, sellaisten ainesten, jotka muuten menisivät roskiin. Kiertotalous on siis kaikkea mahdollista uusio käyttöä, eri toimijoiden välistä yhteistyötä, millä materiaalia saadaan käytettyä uuteen tarkoitukseen. (2020)

(13) Kiertotaloudella kuvataan järjestelmää, jossa jokin asia tai esine voidaan hyödyntää aina uudelleen tai ainakin mahdollisimman pitkään sen jälkeen, kun sen pääasiallinen elinkaari on päättynyt. Kiertotalous merkitsee sitä, että esine tai asia ei päädy käyttökelvottomaksi sen käytön jälkeen, vaan sitä voidaan hyödyntää uusiin tarkoituksiin joko sellaisenaan tai tietyn korjaus-/muokkausprosessin jälkeen. (2020)

Lomakkeen tehtävänannossa puhuteltiin vastaajaa yksikön toisen persoonan muodoin, ja siinä esiintyivät ilmaukset mielestäsi ja mielikuvia. Nämä ovat saattaneet vaikuttaa siihen, että vastauksissa esiintyy hyvin usein evidentiaalista, omaan päättelyyn perustuvaa epävarmuuden ilmaisemista: (minulle) tulee mieleen, sana tuo mieleen, on mielestäni, tarkoittaa mielestäni, herättää ajatuksia jostakin, uskoisin, luulen, voisin kuvitella, ymmärrän. Havaintoon perustuvaa evidentiaalisuutta on vastauksissa, joissa sana herättää mielikuvan, kuulostaa joltakin tai muistelen kuulleeni sanan. Muutamat vastaajat pyrkivät myös yksilöimään ulkopuolisen lähteen (esim. mainos, maantiedon oppikirja), jossa sanaa on käytetty. Esimerkeissä 14 ja 15 on näiden lähteiden lisäksi käytetty myös monia muita episteemisen modaalisuuden ilmaisukeinoja, kuten kysymystä (vai oliko), modaaliverbiä ja konditionaalia (voisi, taisin) ja modaalisia partikkeleita (ebkä, sittenkin, ilmeisesti). 
(14) Olen miettinyt, mitä se voisi tarkoittaa, mutta en ole selvittänyt asiaa. On tullut vastaan ehkä jokin mainos, jossa tätä sanaa on käy tetty... Vai oliko se "tukitalous" sittenkin? (2019)

(15) Ilmeisesti joku talousmalli tms, jossa pyritään kierrättämään ja/tai välttämään jätettä. Maantiedon yo-kirjoituksiin taisin aiheesta lukea. (2020)

Eriasteista episteemistä todennäköisyyttä ilmaistaan siis myös modaalisin adverbein ja partikkelein (VISK $\$ 1601$ ), jollaisia kummankin kyselyn vastauksissa esiintyy useita: ehkä, ehkäpä, hAn, ilmeisesti, kai, kyllä, luultavasti, mahdollisesti, oikeasti, tavallaan, tosin, tuskin, vahvasti, varmaan, varmaankin, varmasti. Myös päättelyä ilmaiseva evidentiaalinen siis esiintyy useissa vastauksissa (ks. esim. 16-19).

(16) Ihan ekana ei tullut mieleen mitään, mutta kun mietin niin ebkä se voisi olla sitä, että raha liikkuu ja joku tietty talouden haara on aina riippuvainen muusta taloudesta jne. Ovat riippuvaisia toisistaan. Mutta en oikeasti tiedä, mitä se tarkoittaa. (2019)

(17) Ensimmäisenä mieleeni tulee kierrätys ja esimerkiksi kirpputorit, vaikka siitä tuskin ilmiössä on kyse. En siis ole tietoinen kiertotalouden merkityksestä tai sanasta ylipäänsä, vaikka tunnistan kuulleeni/ nähneeni sen jossain pari kertaa. (2019)

(18) Pyrkii kai takaamaan tuotteelle mahdollisimman pitkän iän ja hyödyn. Tuotetta siis jalostetaan erilaiseksi ja kierrätetään. (2020)
(19) En ole kyllä yhtään varma mutta liittyisiköhän se jotenkin kierrätykseen? (2020)

Esimerkissä 19 esiintyy modaaliaineksena paitsi partikkelit kyllä ja - $h A n$ myös epävarmuutta ilmaiseva konditionaali. Konditionaalia käytetään episteemisen modaalisuuden ilmaisemiseen myös esimerkissä 20, jossa vastaaja ensin esittää indikatiivimuotoisella väitelauseella varman oloisesti väärän tulkinnan, mutta sen jälkeen antaa "esineiden näkökulmasta" sanalle toisen merkityksen, jonka hän merkitsee epävarmaksi ilmaisulla haluaisin mieltää.

(20) Kiertotalous on rahataloudessa sitä kun raha kiertää ihmisiltä veroja maksettaessa valtiolle ja säästämisellä pankeille ja sitten taas valtiolta raha tulee takaisin ihmisille tukien ja ilmaisten palveluiden muodossa. Esineiden näkökulmasta haluaisin mieltää kiertotalouden kierrätyksen ja uusiutuvien raaka-aineiden muodossa. (2019)

Moduksista potentiaali ilmaisee episteemistä todennäköisyyttä (VISK $₫ 1597)$. Sitä ei juuri esiinny aineistossamme; ainoa potentiaalin sisältävä vastaus on esimerkki 21 .

(21) Liittynee kierrätykseen (2020)

Esimerkissä 19 vastaajan epävarmuutta ilmaisee konditionaaliverbiin liitettynä myös $k O$-liitepartikkeli. $k O$-vaihtoehtokysymys ikään kuin tarjoaa yhden mahdollisen selityksen, jonka paikkansapitävyyden vastaanottaja saa arvioida. Lisäksi sanan lopussa oleva $h A n$-partikkeli merkitsee sanotun epävarmaksi tai vastausta kaipaamattomaksi. (VISK $₫ 1679,1681$.) Kyselyvastauksissa 
esiintyy vaihtoehtokysymysten lisäksi myös pelkkiä kysymysmerkkejä ilmaisemassa vastaajan epävarmuutta (ks. esim. 22 ja 23, joihin sisältyy myös muita episteemisen modaalisuuden ilmaisukeinoja).

(22) En tiedä juurikaan mitään. Kestävä kehitys?? (2019)

(23) Ensimmäisenä tulee mieleen kierrätys. Talous jossa kierrätetään, ehkäpä? Vai onko kyseessä sittenkin vain rahan kiertäminen yhteiskunnassa kuluttajilta yrityksille ja valtiolle, ja niiltä taas kuluttajille. (2019)

\subsection{Kiertotalous-sanan merkityksen päättely}

Edellä esimerkkien 12 ja 13 tyyppiset vastaukset kertovat vastaajan tuntevan kiertotaloussanan merkityksen ja käyttökontekstit hyvin, joten niiden tarkastelu ei ole yhdyssanan merkityksen päättelyn kannalta tarpeellista. Sen sijaan "väärät" vastaukset sekä vastaukset, jotka sisältävät erilaisia episteemisen modaalisuuden ilmauksia, ovat kiinnostavia siltä kannalta, miten vastaaja on rakentanut mielessään yhdyssanan merkitystä. Useimmiten merkitystä on pyritty päättelemään yhdyssanan osien merkitysten tai sanan mahdollisten kontekstien pohjalta, kuten nominatiivisubstantiivialkuiselle yhdyssanalle on tyypillistä. Esimerkissä 24 vastaaja jopa itse tunnistaa tarvitsevansa sanan merkityksen tulkintaan käyttökontekstia ja toteaa, ettei kahden tutun sanan yhdistelmän merkitys aukene ilman sitä, vaikka edusosa tuntuukin viittaavan talouselämän kontekstiin.

(24) Kuulostaa ekonomiaan liittyvältä termiltä mutta täytyy sanoa että ilman kontekstia en tiedä mitä kiertotalous tarkoittaa. Talous on tuttu käsite. Ja kierto myös. Yhdistettynä en tiedä? (2019)
Edusosa talous onkin lähes kaikissa vastauksissa tulkintojen lähtökohtana, onhan kiertotalous tyypillinen määritysyhdyssana, jossa edusosa ilmaisee asian, jota määriteosa tavalla tai toisella rajaa. Monet vastaajat ovat käyttäneet analogisena mallina muita talous-loppuisia yhdyssanoja, joissa edusosan merkitys on yleensä abstrakti 'talouselämä' (esim. valtiontalous) tai 'talouselämää hoitava järjestelmä, jotakin ylläpitävä järjestelmä (esim. markkinatalous, lineaaritalous, vaibdantatalous, energiatalous), ja ovat pyrkineet tulkitsemaan kysytyn sanan vastaavalla tavalla. Lähinnä 'talouselämään' viittaa vastaus 25 , kun taas järjestelmänäkökulma on vahvasti esillä esimerkeissä 26, 27 ja 28, joista kahdessa jälkimmäisessä näkyy myös vastaajan mieleen tullut analoginen mallisana (vaihdantatalous, kansantalous). Huomattakoon myös esimerkistä 26 havaittava käsitteen väljyys (erilaiset asiat kiertävät).

(25) Kiertotalous kertoo sen miten varat (rahalliset, luonnonvarat yms.) voidaan käyttää useaan kertaan taloudessa. Niille voidaan keksiä uusiokäyttömuotoja sekä ne voidaan allokoida tehokkaampaan käyttöön. (2019)

(26) Kiertotalous-sanasta tulee mieleeni systeemi, jossa erilaiset asiat kiertävät. Esimerkiksi voidaan kierrättää asioita ja käyttää niitä uudelleen muualla. (2019)

(27) Mieleeni tulee konsepti, jossa tavarat kiertävät henkilöltä toiselle tarpeen mukaan. Vanhat, itselle turhat ja käyttämättömäksi jääneet tavarat annetaan eteenpäin niitä tarvitseville. Samantapaista kuin vaihdantatalous. (2019)

(28) En tiedä tarkkaa tarkoitusta mutta mieleen tulee jonkinlainen taloudellinen systeemi jonka osat varioivat jotenkin keskenään. 
Käsite liittyy jotenkin kansantalouteen ja sen kiertokulkuun. (2020)

Varsin monen vastaajan mielessä talous-sana herätti konkreettisen mielikuvan rahasta, onhan sanan yksi merkitys 'rahavarat, varallisuus. Esimerkkien 29 ja 30 kaltaisia vastauksia saimme kummassakin kyselyssä useita.

(29) Rahan kiertäminen yhteiskunnassa (2019)

(30) En osaa sanoa. Asiat ja raha liikkuvat ja vaihtavat omistajaa. (2020)

Joissain harvoissa vastauksissa näkyy taloussanan merkitys 'taloudenhoito' (esim. 31) ja jopa 'kotitalous, ruokakunta' (esim. 32).

(31) En ole ikinä kuullut, mutta kuulostaa joltain uudelta menetelmältä hoitaa taloutta (2019)

(32) Muistan kuulleeni sanan ja sen merkityksen joskus, mutta en muista enää tarkkaan. Sana herättää mielessäni jonkinlaisen kuvan ympäristöystävällisestä taloudesta, kenties enemmän pieniin yksiköihin kuten kotitalouksiin keskittyen. Kiertotalous kuulostaa siltä, että varat kiertävät ja ne uusiokäytetään mahdollisimman tehokkaasti. (2020)

Vaikka yhdyssanan ymmärtämisen lähtökohtana on edusosa talous, syntyvät rajautuneemmat merkitystulkinnat määriteosan kierto merkitysten pohjalta. Se on deverbaali $O$-teonnimijohdos, jossa kantaverbin kiertää merkitykset ovat selvästi läsnä. Käsittelemme seuraavaksi Kielitoimiston sanakirjassa esiintyviäkierto- ja kiertää-sanojen eri merkityksiä, joita voidaan nähdä kyselyvastausten merkitystulkintojen pohjana.
Kiertotalouden vakiintuneessa merkityksessä (Sitra, 2016) kierto-määriteosa rajaa talousjärjestelmän suljetuksi kehäksi, jossa tuotteet ja materiaalit pysyvät käytössä arvonsa säilyttäen, eli siinä korostuu kiertää-sanan merkitys 'kulkea ympäri (umpinaista rataa)'. Lisäksi määritelmä sisältää ajatuksen jakamisesta, yhteisomistamisesta ja vuokraamisesta, mikä kytkeytyy kiertää-verbin merkitykseen 'kulkeutua yhdeltä toiselle, vaihtaa omistajaa'. Molemmat merkitystulkinnat ovat nähtävissä kummassakin kyselytutkimuksessa epävarmojenkin vastaajien vastauksissa. Esimerkissä 33 on ympyränmuotoisen radan lisäksi kiinnostava metafora, ketju, joka tuo mukaan toisenkin tason kierron - koostuuhan ketju toisiinsa kytkeytyvistä umpinaisista lenkeistä. Tämä ketju voi siis mennä lineaarisesti jostain jonnekin päätepisteeseen tai muodostaa ympyrän, jolla ei ole päätepistettä. Umpinaiseen kiertorataan viittaa myös metafora kehä (esim. 34). Kätketymmin kierron 'ympäri kulkemisen' merkitys sisältyy esimerkkiin 35.

(33) Kiertotalous liittyy ympyränmuotoiseen ketjuun, sen sijaan että ketju menisi lineaarisesti, ketjulla on päätepiste, mutta ympyrässä kaikki hyötykäytetään uudelleen, eikä ole niin sanottua jätettä tai hukkaa. (2019)

(34) Taloudessa olevat tuotteet ja resurssit kiertäisivät mahdollisimman pitkään. Mielikuvana toimii hyvin kehä. (2020)

(35) Kiertotalous liittyy resurssien uudelleenkäyttöön, ympäristöä säästäen. (2020)

Tavallisin kierto-sanaan liittyvä tulkinta vastauksissa vaikuttaa olevan kuitenkin 'siirtyminen yhdeltä toiselle' (< kiertää 'kulkeutua yhdeltä toiselle, vaihtaa omistajaa'). Puhutaan kierrättämisestä ja jakamisesta, kuten esimerkissä 36. Kierrättäminen esiintyykin esimer- 
kin 37 tapaan hyvin monissa vastauksissa. Tämä tapa ymmärtää kierto-määriteosa ei kuitenkaan välttämättä johda kokonaisuuden oikeaan tulkintaan, jos talous-sana on johdattanut ajatukset erityisesti rahaan. Esimerkin 38 kaltaiset vastaukset ovat kummassakin kyselyssä varsin yleisiä.

(36) Kiertotaloudessa hyödykkeitä ei omisteta yksin vaan niitä jaetaan muiden kanssa tarpeen mukaan. Mieleen tulee esim. auton tai kodinkoneen kierrättäminen/ jakaminen. (2019)

(37) Kiertotalous herättää minussa hyvin vahvan mielikuvan kierrättämisestä. (2020)

(38) semmoinen mielikuva, että liittyy varmaankin jotenkin rahan kiertoon ihmiseltä toiselle, mutta tarkemmin en osaa sanoa (2020)

Ei niinkään kehän kiertäminen vaan ylipäätään pyörivä, etenevä liike on havaittavissa niissä vastauksissa, joissa käytetään liikkumiseen viittaavia ilmauksia. Liikkeessä olevaksi voidaan mieltää raha (39-41, ks. myös 29) tai erilaiset muut tuotannon tekijät, kuten työvoima (42).

(39) Kiertotaloudessa yhteiskunnan varoja laitetaan kiertämään yhteisen hyvän vuoksi ja näin saadaan asiat rullaamaan. (2019)

(40) Kiertotalous on tärkeää, koska silloin tuotannontekijät ja pääoma saadaan liikkeelle. (2019)

(41) Ihan ekana ei tullut mieleen mitään, mutta kun mietin niin ehkä se voisi olla sitä, että raha liikkuu ja joku tietty talouden haara on aina riippuvainen muusta taloudesta jne. Ovat riippuvaisia toisistaan. Mutta en oikeasti tiedä, mitä se tarkoittaa. (2019)
(42) En ole varma ehkä tarkoittaa sitä, että ibmiset liikkuvat paljon ammatista toiseen ja kiertävät työalalta toiseen. (2019)

Esimerkissä 41 nousee esiin myös eri asioiden välinen riippuvuus- tai hyötymissuhde. Tällainen mielikuva on herännyt varsin monelle vastaajalle (esim. 43-45); se juontuu mahdollisesti siihen, että kierto yhdistyy sekä 'pyörivään, etenevään liikkeeseen' että 'siirtymiseen yhdeltä toiselle'.

(43) En tiedä, mutta aavistukseni mukaan se tarkoittaa tilannetta, jossa eri teollisuudet toimivat ikään kuin toisilleen. "Kierto" täten tarkoittaisi sitä, että kaikki teollisuus ja talous toimivat edellytyksinä toisilleen. (2019)

(44) Kiertotalous: kysynnän ja tarjonnan laki, ei ylimääräisiä turhakkeita. (2019)

(45) Sitä, että tehdään työtä, josta toiset hyötyvät jollain tavalla ja että niin tavarat kuin tiedot ja taidotkin kiertävät ja hyödyttävät toisia. Koskee kaikkia elämän osa-alueita. (2020)

Kierto-sanan yksi erikoismerkitys on 'viljelykasvien vuorottelu jollakin viljelyalalla' (Kielitoimiston sanakirja, 2018). Kiintoisasti myös tämä merkitys näkyy muutamissa vastauksissa (esim. 46 ja 47):

(46) Kiertotalous tuo ensimmäisenä mieleen vuoroviljelyn. (2019)

(47) Ensimmäiseksi mieleen tulee maatalous. Kiertotaloudella pyritään mielestäni sekä ympäristöystävällisempään viljelyyn että tehokkaampaan viljelyyn siten että esimerkiksi talvikuukaudetkin pyritään ottamaan hyötykäyttöön. (2019) 
Sekä vuoden 2019 että 2020 kyselyssä on monia vastauksia, joissa kiertotaloutta pidetään kielteisiä mielikuvia herättävänä sanana. Jotkin tämäntyyppisistä vastauksista liittyvät ilmeisesti talous-sanan herättämään vastenmielisyyteen (ks. esim. 48), mutta yleensä negatiivisena koetaan nimenomaan kierto-sanan synnyttämä mielikuva. Silloin tulkinnan tuottaa lähinnä kiertää-verbin merkitys 'kaartaen sivuuttaa, välttää, karttaa, kaihtaa. Kun talous liitetään rahaan ja kierto karttamiseen, syntyy ajatus sääntöjen ja vastuiden, kuten verojen tai palkanmaksun, välttelystä (esim. 49-51).

(48) En tiedä, mitä sana tarkoittaa enkä mihin se liittyy. Mielikuvina herää raha ja politiikka. Aihe ei kiinnosta minua. (2019)

(49) En ole koskaan edes kuullut kiertotaloudesta. Sanana kiertotalous tuo mieleen jonkinlaisen vastuun pakoilemisen, esim. veroparatiisit (2019)

(50) Liittyy harmaaseen talouteen, kierretään veronmaksua ja maksetaan huonompaa palkkaa. Toisinsanoen, kierretään taloutta laittomin keinoin. (2019)

(51) Yrittää kiertää joidenkin sääntöjen ympäri? Negatiivinen konnotaatio tulee minulle termistä, en tiedä miksi. (2019)

Kierto- jakiertää-sanojen eri merkitykset näkyvät siis varsin laajasti kyselyyn vastanneiden kuvauksissa. Jopa aktiivista ihmistoimijaa edellyttävä merkitys 'pyörittää, vääntää voidaan ajatella esimerkin 52 vastauksen herättäjäksi. Sanakirjamerkityksistä ainoastaan 'kulkea kaartaen, kiertoteitse' sekä päämäärätön 'kuljeksia, harhailla' eivät näille vastaajille näytä tarjoavan merkityksen tulkinnan avaimia.

(52) Taloudellinen ilmiö millä pyritään nostamaan tuotteen hintaa (2019)

\section{YHTEENVETO}

Kiertotalous on eri tieteenaloilla ja poliittisessa diskurssissa tunnettu erikoiskielen sana, joka esiintyy yhä useammin myös yleiskielisissä konteksteissa. Yleiskielisessä käytössä sitä voidaan pitää uudissanana, jonka merkitys ei välttämättä kansalaisille ole vielä kovin tuttu. Olemme tässä tutkimuksessa selvittäneet, miten toisen asteen koulutuksen suorittaneet, pääasiassa alle 30-vuotiaat nuoret aikuiset ymmärtävät sanan merkityksen ja millaisia muutoksia ymmärtämisessä on puolentoista vuoden aikana tapahtunut.

Tutkimustulokset osoittavat, että kevään 2019 ja syksyn 2020 välillä niin kiertotaloussanan ymmärtämisessä kuin myös itse asiaan suhtautumisessa on tapahtunut merkittävä muutos. Kun ensimmäisessä kyselyssä vain alle puolet vastaajista osasi antaa sanalle edes jossain määrin oikeansuuntaisen selityksen, tiesi toisen kyselyn vastaajista jo lähes 80 prosenttia yhdistää sanan johonkin tai joihinkin sanalle vakiintuneisiin merkityspiirteisiin. Lisäksi jälkimmäisen kyselyn vastaukset antavat kiertotaloudesta monipuolisemman ja laajemman kuvan kuin ensimmäisen kyselyn vastaukset, joissa esiintyy myös paljon enemmän epävarmuutta ilmaisevia aineksia. Kiinnostus kiertotaloutta koskevaan keskusteluun oli ajanjakson kuluessa lisääntynyt ja asenteet nyt jo paremmin tunnettua kiertotaloutta kohtaan muuttuneet selvästi myönteisemmiksi.

Muutoksen syitä voi olla monia, eikä niitä ole mahdollista tämän tutkimuksen perusteella kuin arvailla. Yksi todennäköinen selitys on sanan lisääntynyt käyttö julkisessa keskustelussa ja sen näkyminen mediassa. Näin on tapahtunut ainakin Helsingin Sanomien ja Ilta-Sanomien tarkastelun perusteella: sanan osumat kummankin lehden jutuissa ovat lisääntyneet tutkimusaikana selvästi. Tarkemman kuvan saamiseksi ajanjaksolta pitäisi tutkia myös sosiaalisen median kanavilla käytyjä keskusteluja, oppikirjoja, mainontaa ja muuta yritysten kuluttajaviestintää. 
Vastausten modaalisista aineksista voi havaita, että useat kyselyvastaajat joutuivat päättelemään sanan merkitystä pelkästään yhdysosien perusteella. Yksittäiset vastaajat (esim. 53) pohtivat tietoisestikin yhdysosien merkitystä ja ehdottavat sitä kautta sanalle erilaisia merkitysvaihtoehtoja. Epävarmuutta ilmaistaan vastauksissa eri tavoin, kuten modaaliverbein, partikkelein ja kysymyksin. Ilman kontekstia tulkitseminen on hankalaa, jos sanan merkitys ei ole ennestään tuttu.

(53) Jotain sellaista, että joko resursseja (materiaaleja tms.) tai rahaa kierrätetään. En tiedä kunnolla. Herättää tavallaan positiivisia mielikuvia (kierto - kierrätys), tavallaan negatiivisia mielikuvia (kierto - veronkierto tms. huijaus) (2019)

Odotuksenmukaista oli, että suuri osa vastaajista yhdisti sanan kiertotalous kierrättämiseen. Sanalle sopivaa kontekstia etsittiin siis kiertää-sanan merkityksen 'kulkeutua yhdeltä toiselle, vaihtaa omistajaa' kautta. Tyypillisesti vastaajat ajattelivat byödykkeiden, tavaroiden, esineiden tai tuotteiden kierrättämistä uusille käyttäjille. Jälkimmäisessä kyselyssä esiintyi kuitenkin ensimmäistä selvästi useampia mainintoja myös materiaalien, resurssien tai luonnonvarojen uusiokäytöstä, kierrosta, ja monessa niistä esiintyy metaforana kehä, kaari tai suljettu ketju. Vakiintuneissa määritelmissähän kiertotalous kuvataan paljolti mallina, joka on lineaaritalouden vastakohta, eli talousjärjestelmiä verrataan toisaalta viivaan, jolla on alku- ja loppupiste, ja toisaalta ikuisesti kiertävään kehään. Myös lineaaritalous lienee kuitenkin suhteellisen vieras käsite, sillä siihen ei viitattu kuin yhdessä vastauksessa (ks. esim. 33). Yksi syy kiertotalous-sanan hankaluuteen voikin olla, ettei tulkinnan apuna olevaa metaforaa lineaarisen ketjun sulkemisesta tunneta.
Yllättävämpää oli se, että talous-sanan merkitys 'rahavarat, varallisuus' vaikutti erittäin monien vastaajien tulkintoihin. Kiertotalous yhdistettiin nimenomaan rahaan: joko rahan kiertämiseen yhteiskunnassa, jossa tapauksessa kierto-sanan merkitys ymmärrettiin 'kierrättämisenä' tai 'kehän kiertämisenä, tai rahallisten velvoitteiden kiertämiseen, ennen kaikkea veronkiertoon, jossa tapauksessa kierto-sanaa tulkittiin 'välttämisen, kaihtamisen' merkityksen kautta.

Muutamat opiskelijat pyrkivät vastauksessaan vain lähinnä kontekstoimaan käsitteen esittämättä sille varsinaista merkityksen tulkintaa. Kiertotalous osattiin yhdistää ympäristö-, ekologia- ja ilmastokysymyksiin sekä kestävään kehitykseen, kuten esimerkeissä 54 ja 55. Joillekuille sana yhdistyi yleisemmällä tasolla poliittiseen diskurssiin (esim. 56) tai vain johonkin tärkeään (esim. 57). Eräänlaista kontekstointia pyrkii tekemään myös esimerkin 58 vastaaja, joka määrittelee kiertotaloustoimijoiksi hipit ja vasemmistolaiset.

(54) Ympäristökysymykset, ekologinen ajattelu (2020)

(55) En tiedä juurikaan mitään. Kestävä kehitys?? (2019)

(56) En tiedä, mitä sana kiertotalous merkitsee, mutta sanan perusteella se liittyy talousasioiden lisäksi yhteiskuntaan \& politiikkaan / yhteiskunnalliseen keskusteluun. (2019)

(57) En ole kuullutkaan, mutta se kuulostaa tärkeältä (2019)

(58) Kiertotaloudessa ihmiset vaihtavat palveluita ja tuotteita ilman, että raha vaihtaa omistajaa. Kiertotaloutta [sic] harrastavat mielikuvissani hipit ja vasemmistolaiset. (2019) 


\section{PÄÄTELMÄT}

Jos Suomi aikoo visionsa mukaan olla kiertotalouden edelläkävijämaa ja hiilineutraali kiertotalousyhteiskunta vuonna 2035, on uusi talousmalli tehtävä tunnetuksi ja hyväksyttäväksi yhteiskunnan kaikilla eri tasoilla. Tärkeä merkitys on paitsi yritysten, lainsäätäjien ja kuntien hallinnon konkreettisilla toimilla myös kansalaisten tahdolla ja valmiuksilla toimia kiertotalouden periaatteiden mukaisesti. Kuten Ken Webster (2013: 544) on todennut, uuden talousmallin iskostaminen ei onnistu pelkkiä faktoja kuvaamalla. Sen sijaan muutosta pitää rakentaa puhumalla siitä erilaisissa yhteyksissä, eri kehyksissä ja niihin sopivien metaforien avulla.

Toistaiseksi suuri yleisö tuntee kiertotalouden käsitteen vielä varsin heikosti. Tutkimiemme yliopisto-opiskelijoiden yleinen tietotaso yhteiskuntaan ja ympäristöön liittyvissä asioissa on todennäköisesti keskimääräistä kansalaista korkeampi, joten vaikka vastaajajoukko edustaa vain pientä valikoitua väestönosaa, voidaan olettaa, ettei yleinen tietämys kiertotaloudesta ole ainakaan tutkimusjoukkoamme parempi. Toisaalta jo tutkimamme lyhyen ajanjakson sisällä tunnettuus opiskelijoiden keskuudessa on selvästi lisääntynyt, mikä saattaa viitata samanlaiseen muutokseen myös muiden kansalaisten ymmärryksessä.

Abstrakteja käsitteitä kiteyttävät erikoistermit ovat käytännöllisiä, kun aiheeseen vihkiytyneet asiantuntijat, viranhaltijat, päättäjät ja yritykset keskustelevat keskenään, mutta niiden tiivis sisältö ei avaudu tavallisille kansalaisille. Sen sijaan kiertotalouden kaltaisen, tutuista aineksista koostuvan, mutta sisällöltään vieraan erikoistermin tulkinta johtaa kunkin omista ajattelutavoista kumpuaviin arvailuihin, jotka saattavat olla jopa haitallisia itse asian edistämisen kannalta.
Hallinto- ja strategiapuhe ei tavoita useimpia kansalaisia, eikä erikoiskielinen ilmaisutapa avaudu sitä ennestään tuntemattomalle. Kiertotalouden ydinajatukset tuleekin konkretisoida suurelle yleisölle esimerkkien, metaforien ja tarinoiden avulla laajalti ja toistuvasti niin mediassa kuin myös yritysten kuluttajaviestinnässä. Vallitseva mielikuva on, että kiertotalous on pelkkää tavaroiden kierrättämistä ja siten niiden hyötykäyttöajan pidentämistä. On tärkeää, että kansalaiset ymmärtävät kiertotalouden tätä laajemmin. Jätteiden lajittelu on jo suuri askel materiaalikierron suuntaan, mutta esimerkiksi yhteisomistajuutta, vuokraamista tai korjauspalveluja tuskin toistaiseksi kovin laajasti mielletään osaksi samaa talousmallia, jonka perimmäisenä tavoitteena on estää luonnonvarojen ylikuluttaminen ja ympäristöhaitat taloutta kuitenkaan pysäyttämättä. 


\section{LÄHTEET}

\section{Aineslähteet}

Kiertotalouskysely v. 2019 ja v. 2020. Aineisto tekijöiden hallussa.

Sanoma-arkisto. Helsingin Sanomien arkisto ja Ilta-Sanomat. Verkkoaineisto. Tietokannan käyttöliittymä https://yritysarkisto.sanoma. fi/login. Haettu 23.11.2020.

\section{Muut lähteet}

Aikhenvald, A. (2018). Evidentiality: The framework. A. Y. Aikhenvald (toim.), The Oxford handbook of evidentiality. Oxford Handbooks in Linguistics. Oxford University Press. Online publication. DOI: 10.1093/ oxfordhb/9780198759515.001.0001

CICAT2025. "Kiertotalouden katalyytit: innovaatioekosysteemeistä liiketoimintaekosysteemeihin". https://cicat2025. turkuamk.fi/fi/cicat2025/.

Coseriu, E. (1971). Sprache. Strukturen und Funktionen. XII Aufsätze. 2., verbesserte Auflage. Spangenberg KG, Tübingen.

- - - 1975: Sprachtheorie und allgemeine Sparchwissenschaft. Bd. 2. Internationale Bibliothek für allgemeine Linguistik, München. Elsayed, D. (2017). Agricolan pitää-nesessiiviverbi kielikontaktin ytimessä. Annales Universitatis Turkuensis C: 448. Scripta Lingua Fennica Edita. Turku: Turun yliopisto.

Kansalliskirjasto, digitaaliset sanomalehtiaineistot. Saatavissa: digi.kansalliskirjasto.fi/collections. Haettu 27.5.2021.

Karihalme, O. (1996). Muotoilun teoriasanaston termistyminen. Acta Wasaensis 51. Kielitiede 10. Vaasa: Vaasan yliopisto.

Kielitoimiston sanakirja 2018. Kotimaisten kielten keskuksen verkkojulkaisuja 58. Helsinki: Kotimaisten kielten keskus ja Kielikone Oy. Viitattu 28.12.2020. Saatavissa: URN:NBN:fi:kotus-201434.

Kiertotalouden ekosysteemit. Työ- ja elinkeinoministeriön julkaisuja 2020: 13. Helsinki: Työ- ja elinkeinoministeriö. Viitattu 10.12.2020. Saatavissa: http://urn.fi/ URN:ISBN:978-952-327-500-3.

Kiertotalousohjelman kansalaisrati. Ympäristöministeriön asettaman kansalaisraadin verkkotapaamisten muistiot 24.6.2020, 15.10 .2020 ja 12.11.2020. Viitattu
10.12.2020. Saatavissa: https://ym.fi/-/ kiertotalousohjelman-kansalaisraati-visiohyvasta-tulevaisuudesta-auttaa-ratkaisemaankestavyyshaastetta.

Kiviniemi, E. (1987). Voidaanko nimeämisperusteet luokitella? Eero Kiviniemi ja Ritva Liisa Pitkänen (toim.), Kieli 2 (s.7-34). Helsinki: Helsingin yliopiston suomen kielen laitos.

Kotus, uudissanapoiminnat $2014=$ Kotimaisten kielten keskus: Sanapoimintoja vuodelta 2014. Viitattu 16.12.2020. Saatavissa: https://www. kotus.fi/sanakirjat/kielitoimiston_sanakirja/ uudet_sanat/vuoden_sanapoiminnot/ sanapoimintoja_2014\# $\overline{\mathrm{HK}}$.

Laine, P. (2007). Suomi tiellä sivistyskieleksi. Suomenkielisen maantieteen sanaston kehittyminen ja kehittäminen 1800-luvulla. Turun yliopiston suomalaisen ja yleisen kielitieteen laitoksen julkaisuja 77. Turku: Turun yliopisto.

Läärä, H. (2020). Kiertotalous-sanan semanttiset kehykset ja diskurssit Helsingin Sanomien teksteissä. Pro gradu -tutkielma. Kieli- ja käännöstieteiden laitos, suomen kieli. Turku: Turun yliopisto.

Nuutinen, L. (2014). Kierrätystä kiertotaloudessa. Kielikello 3/2014. Helsinki: Kotimaisten kielten keskus. Viitattu 16.12.2020. Saatavissa: https:// www.kielikello.fi/-/kierratysta-kiertotaloudessa Pitkänen, K. (2008). Suomi kasvitieteen kieleksi. Elias Lönnrot termistön kebittäjänä. SKST 1164. Helsinki: Suomalaisen Kirjallisuuden Seura.

Seppänen, L. (1981). Nominaalikompositumien semantiikkaa. Sananmuodostuksen ongelmia. Seminaari Seilissä 3.-4.9.1981, 69-82. SKYJ 7. Turku: Turun yliopisto.

Sitra, 2016. Kiertotalous > Mistä on kyse? Helsinki: Sitra, Suomen itsenäisyyden juhlarahasto. Viitattu 9.12.2020. Saatavissa: https://www. sitra.fi/aiheet/kiertotalous/\#mista-on-kyse.

Sumter, D., de Koning, J., Bakker, C. \& Balkenende, R. (2020). Circular economy competencies for design. Sustainability 12, 1561. https://doi. org/10.3390/su12041561.

Tieteen termipankki 31.12.2020. Kielitiede: modaalisuus. Saatavissa: https://tieteentermipankki.fi/wiki/ Kielitiede:modaalisuus. 
Tyysteri, L. (2015). Aamiaiskahvilasta ötökkätarjontaan. Suomen kirjoitetun yleiskielen morfosyntaktisten yhdyssanarakenteiden produktiivisuus. Turun yliopiston julkaisuja C: 408. Scripta Lingua Fennica Edita. Turku: Turun yliopisto.

Uusi suunta. Ehdotus kiertotalouden strategiseksi ohjelmaksi. Valtioneuvoston julkaisuja 2021:1. Helsinki: Valtioneuvosto. Viitattu 22.1.2021. Saatavissa: http://urn.fi/ URN:ISBN:978-952-383-658-7

Ympäristöministeriö. Kiertotalouden strateginen ohjelma. Viitattu 9.12.2020. Saatavissa: https:// ym.fi/kiertotalousohjelma.

Virsu, V. \& Sjöblom, P. (2020). Kiertotalouden kehykset: vertailussa viranomaisviestintä ja kansalaisten määritelmät. Media ja viestintä, 43, 227-247.

VISK = Auli Hakulinen, Maria Vilkuna, Riitta Korhonen, Vesa Koivisto, Tarja Riitta Heinonen ja Irja Alho 2004: Iso suomen kielioppi. Helsinki: Suomalaisen Kirjallisuuden Seura. Verkkoversio. Viitattu 16.12.2020. Saatavissa: http://scripta. kotus.fi/visk URN:ISBN:978-952-5446-35-7.

Webster, K. (2013). What might we say about a circular economy? Some temptations to avoid if possible. World Futures 69 (7-8), 542-554. DOI: $10.1080 / 02604027.2013 .835977$

Winans, K., Kendall, A. \& Deng, H. (2017). The history and current applications of the circular economy concept. Renewable and Sustainable Energy Reviews, 68, 825-833. DOI: 10.1016/j. rser.2016.09.123

WWF. Globaalit uhat. Viitattu 9.12.2020. Saatavissa: https://wwf.fi/uhat/.

Zgusta, L. (1990). Onomasiological change: Sachen-change reflected by Wörter. Edgar C. Polome (toim.), Research guide on language change, 389-398. Trends in Linguistics Studies and Monographs 48. Berlin: Mouton de Gruyter. 


\section{RECOGNITION AND INTERPRETATIONS OF THE FINNISH WORD KIERTOTALOUS 'CIRCULAR ECONOMY'}

Paula Sjöblom, University of Turku, School of Languages and Translation Studies

Ville Virsu, University of Turku, Centre for Language and Communication Studies

One possible solution to the global problems is sustainable circular economy. It is an economic model, which supports limiting climate change and curbing overconsumption of natural recourses and which at the same time strengthens economy and employment. The transfer to a new model requires understanding of the concept. However, the word for 'circular economy' is not very familiar to the public.

This paper investigates how the Finnish word kiertotalous 'circular economy' is recognised by first-year students. The survey was carried out among language students and business students in the universities of Turku and Eastern Finland in 2019 and 2020. The research questions are as follows: How do the students infer the meaning of the compound word on the grounds of its parts? How do they express epistemic modality, i.e. the degree of certainty, in their response? What kind of attitudes the respondents have towards circular economy? How has the recognition of the word changed in 1.5 years?

The results show that kiertotalous has become clearly more familiar during the research period and the certainty has increased, though different means of expressing uncertainty are common in both surveys.

Keywords: circular economy, compounds, meaning, modality 